\title{
Assessment of Gasoline Additive Containing Ditert-butoxypropanol
}

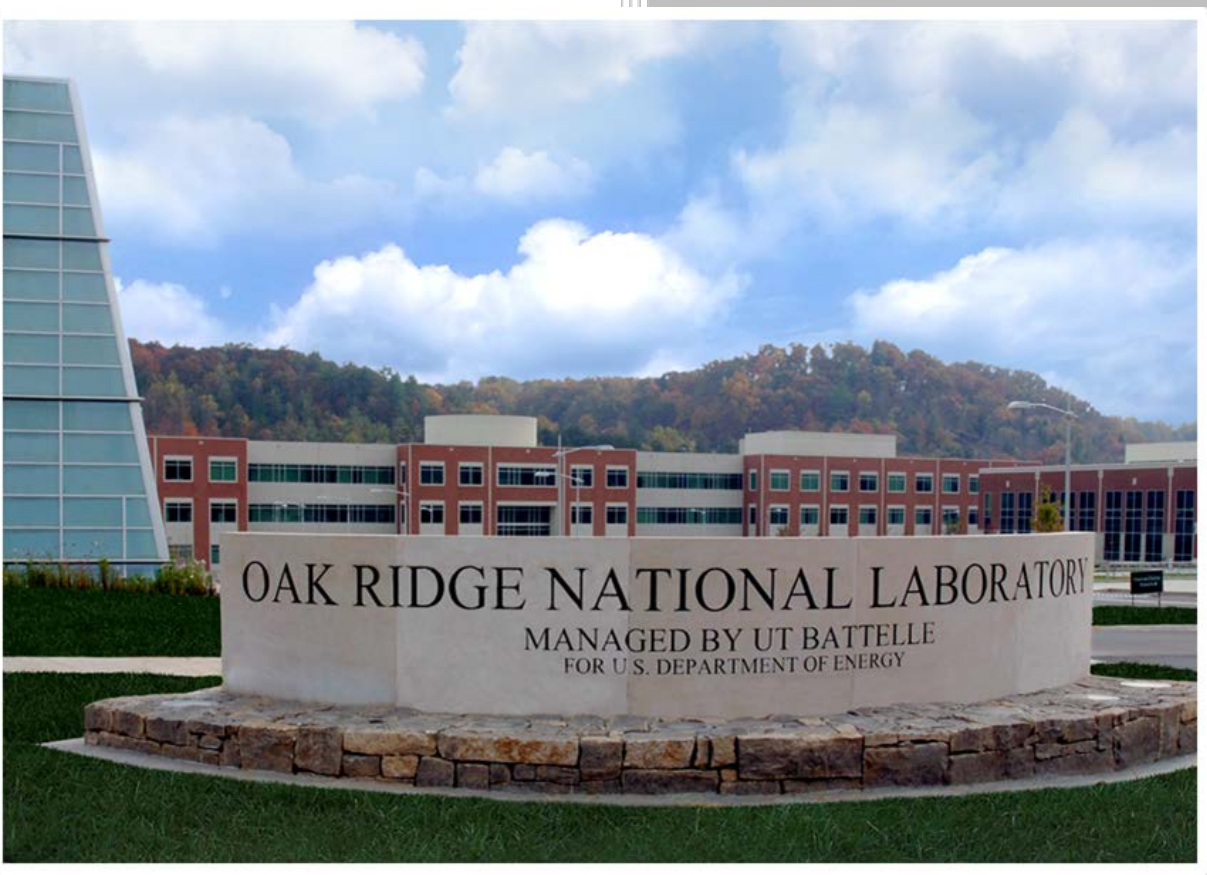

B.H. West

R.M. Connatser

S.A. Lewis

April 2016

Approved for public release; distribution is unlimited. 


\title{
DOCUMENT AVAILABILITY
}

Reports produced after January 1, 1996, are generally available free via US Department of Energy (DOE) SciTech Connect.

\section{Website http://www.osti.gov/scitech/}

Reports produced before January 1, 1996, may be purchased by members of the public from the following source:

\author{
National Technical Information Service \\ 5285 Port Royal Road \\ Springfield, VA 22161 \\ Telephone 703-605-6000 (1-800-553-6847) \\ TDD 703-487-4639 \\ Fax 703-605-6900 \\ E-mail info@ntis.gov \\ Website http://www.ntis.gov/help/ordermethods.aspx
}

Reports are available to DOE employees, DOE contractors, Energy Technology Data Exchange representatives, and International Nuclear Information System representatives from the following source:

Office of Scientific and Technical Information

PO Box 62

Oak Ridge, TN 37831

Telephone 865-576-8401

Fax 865-576-5728

E-mail reports@osti.gov

Website http://www.osti.gov/contact.html

This report was prepared as an account of work sponsored by an agency of the United States Government. Neither the United States Government nor any agency thereof, nor any of their employees, makes any warranty, express or implied, or assumes any legal liability or responsibility for the accuracy, completeness, or usefulness of any information, apparatus, product, or process disclosed, or represents that its use would not infringe privately owned rights. Reference herein to any specific commercial product, process, or service by trade name, trademark, manufacturer, or otherwise, does not necessarily constitute or imply its endorsement, recommendation, or favoring by the United States Government or any agency thereof. The views and opinions of authors expressed herein do not necessarily state or reflect those of the United States Government or any agency thereof. 


\title{
ASSESSMENT OF GASOLINE ADDITIVE CONTAINING DITERT-BUTOXYPROPANOL
}

\author{
B.H. West \\ R.M. Connatser \\ S.A. Lewis \\ Oak Ridge National Laboratory
}

Date Published: April 2016

Prepared by

OAK RIDGE NATIONAL LABORATORY

Oak Ridge, Tennessee 37831-6283

managed by

UT-BATTELLE, LLC

for the

U.S. DEPARTMENT OF ENERGY

under contract DE-AC05-00OR22725 



\section{CONTENTS}

Page

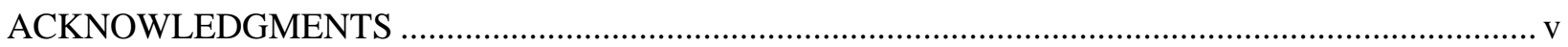

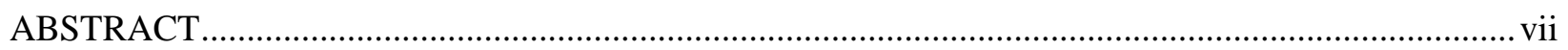

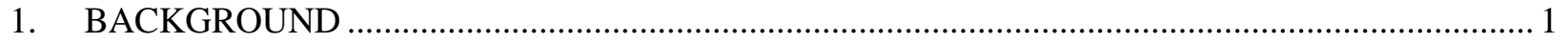

2. ANAL YSIS AND TESTING OF CPS POWERSHOT ADDITIVE .............................................

2.1 ORNL ANAL YSIS ........................................................................................... 2

2.2 FUEL BLENDING AND ASTM TESTING ............................................................... 2

2.2.1 DISTILLATION AND RVP RESULTS ..................................................... 5

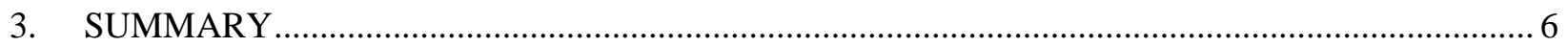

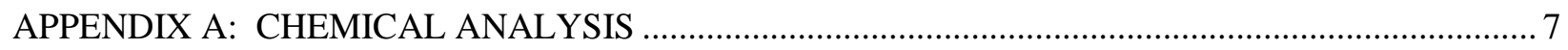

APPENDIX B: SOUTHWEST RESEARCH INSTITUTE TEST REPORTS...................................9 



\section{ACKNOWLEDGMENTS}

This report and the work described were sponsored by the U.S. Department of Energy (DOE) Vehicle Technologies Office (VTO). The authors gratefully acknowledge the support and direction of Kevin Stork at VTO. The authors are indebted to Jim Szybist for his technical guidance during the study and his review of the manuscript. Thanks also to Ron Graves, Robert Wagner, and Keith Kahl at ORNL for their programmatic vision and to Larry Moore for his assistance with fuel blending. The timely and accurate execution of numerous ASTM tests by Southwest Research Institute is also greatly appreciated. 


\begin{abstract}
The Fuels, Engines, and Emissions Research Center completed analysis and testing of the CPS Powershot gasoline additive under the auspices of the Department of Energy's Technical Assistance for US Small Businesses in Vehicle Technologies. Gas chromatography-mass spectrometry (GC-MS) was used to quantify the makeup of the additive, finding a predominance of 2,3-Ditert-Butoxypropanol, also known as Glyceryl Di-Tert-Butyl Ether (GTBE). Blends of the additive at 2 and 4 volume percent were subjected to a number of standard ASTM tests, including Research Octane Number, Motor Octane Number, distillation, and vapor pressure. Results show a high boiling range and low vapor pressure for the additive, and a very modest octane boosting effect in gasoline with and without ethanol.
\end{abstract}




\section{BACKGROUND}

The efficiency of modern spark-ignition engines is limited by knock, especially with the widespread growth in the use of turbocharged, direct-injection engines. The use of high-octane fuels can enable more optimized combustion phasing, allowing for improved efficiency. Recently published data ${ }^{1,2,3,4,5,6}$ highlight the potential fuel economy benefits of high-octane fuels that take advantage of ethanol's properties in a mid-level blend. Two paths to higher octane fuel include more intensive refinery operations, which can impact cost and yield, and increased ethanol blending, which raises concerns about infrastructure and vehicle compatibility. A third, less explored path could involve the use of an octaneboosting additive.

CPS Powershot is a registered oxygenated fuel additive, Glyceryl Di-Tert-Butyl Ether (GTBE), marketed as an octane booster. The ORNL effort explored the chemical makeup of the Powershot additive and further examined the effect of the additive on three relevant gasoline fuels.

\footnotetext{
${ }^{1}$ Leone, T., Olin, E., Anderson, J., Jung, H. et al., "Effects of Fuel Octane Rating and Ethanol Content on Knock, Fuel Economy, and CO2 for a Turbocharged DI Engine," SAE Int. J. Fuels Lubr. 7(1):9-28, 2014, doi:10.4271/2014-01-1228

${ }^{2}$ Splitter, D.A., and Szybist, J.P., "Experimental Investigation of Spark-Ignited Combustion with High-Octane Biofuels and EGR. 2. Fuel and EGR Effects on Knock-Limited Load and Speed,” Energy \& Fuels, 28(2): 1432-1445, 2014, doi:10.1021/ef401575e

${ }^{3}$ Jung, H., Leone, T., Shelby, M., Anderson, J. et al., "Fuel Economy and CO2 Emissions of Ethanol-Gasoline Blends in a Turbocharged DI Engine," SAE Int. J. Engines 6(1):422-434, 2013, doi:10.4271/2013-01-1321.

${ }^{4}$ Splitter, D. and Szybist, J., "Intermediate Alcohol-Gasoline Blends, Fuels for Enabling Increased Engine Efficiency and Powertrain Possibilities," SAE Int. J. Fuels Lubr. 7(1):2014, doi:10.4271/2014-01-1231.

${ }^{5}$ Thomas, John, Brian West, and Shean Huff, "Effects of High-Octane Ethanol Blends on Four Legacy Flex-Fuel Vehicles, and a Turbocharged GDI Vehicle,” ORNL/TM-2015/116, March 2015

${ }^{6}$ Theiss, Tim, et al., “Summary of High-Octane Mid-Level Ethanol Blends Study,” ORNL/TM-2016/42, 2016.
} 


\section{ANALYSIS AND TESTING OF CPS POWERSHOT ADDITIVE}

\subsection{ORNL ANALYSIS}

Gas chromatography-mass spectrometry (GC-MS) was used to quantify the makeup of the CPS Powershot additive. A detailed description of the method and findings are in Appendix A of this report. In summary, ORNL chemists found that the additive is largely comprised of 3 isomers of the diether form of GTBE or 2,3-Ditert-Butoxypropanol. These isomers make up some $83 \%$ of the Powershot additive, with an additional $16 \%$ of olefinic impurities found, and $1 \%$ monoether isomers.

\subsection{FUEL BLENDING AND ASTM TESTING}

The antiknock index (AKI) noted on fuel dispensers in the US is based on two standard Octane Number tests, the ASTM D2699 Research Octane Number (RON) Test ${ }^{1}$, and the ASTM D2700 Motor Octane Number (MON) Test ${ }^{2}$. Both tests are conducted in a special CFR test engine, but under different conditions. The AKI is the average of the RON and MON, given by (RON+MON)/2 and denoted on fuel dispensers as $(\mathrm{R}+\mathrm{M}) / 2$.

Another important ASTM measurement for gasoline is the D86 Test Method for Distillation of Liquid Fuels $^{3}$. The ASTM D4814 Standard Specification for Automotive Spark-Ignition Engine Fuel ${ }^{4}$ provides the requirements for fuel for gasoline engines, including limits on the distillation temperatures (given by the D86 test).

The CPS Powershot additive was blended at 2 and 4 volume percent with three base stocks: 91 RON E0 ${ }^{5}$ gasoline, 72 RON E0 natural gasoline, and 93 RON E10. While CPS Powershot is EPA approved for use at 2 volume \%, blends at 4 volume \% were evaluated for research purposes. Both E0 and E10 fuels were tested to assess whether there was any synergistic effect of the CPS Powershot additive and ethanol. The low octane natural gasoline was tested because it is an abundant, low value, high-volatility gasoline that is commonly used as ethanol denaturant (as well as a diluent for heavy Canadian oil sands). Natural gasoline can also be upgraded in the refinery or potentially blended with high volumes of high-octane blendstocks to produce a marketable gasoline. Ethanol is known to provide a more significant octane boost to lower octane blendstocks ${ }^{6}$; thus it was deemed worthwhile to examine whether CPS Powershot had a similar effect on a low octane gasoline.

Standard ASTM tests were conducted at Southwest Research Institute, in San Antonio, TX. Selected results are discussed in this letter report; all test results are included in Appendix B.

\footnotetext{
${ }^{1}$ ASTM D2699, “Standard Test Method for Research Octane Number of Spark-Ignition Engine Fuel,” available at http://www.astm.org/Standards/D2699.htm

${ }^{2}$ ASTM D2700, “Standard Test Method for Motor Octane Number of Spark-Ignition Engine Fuel, “ available at http://www.astm.org/Standards/D2700.htm

${ }^{3}$ ASTM D86, "Standard Test Method for Distillation of Petroleum Products and Liquid Fuels at Atmospheric Pressure," available at http://www.astm.org/Standards/D86.htm

${ }^{4}$ ASTM D4814, “Standard Specification for Automotive Spark-Ignition Engine Fuel,” available at http://www.astm.org/Standards/D4814.htm

${ }^{5}$ When describing gasoline and ethanol blends, the industry frequently refers to gasoline/ethanol blends with Exx nomenclature, where the $\mathrm{E}$ denotes ethanol and the $\mathrm{xx}$ indicates the volume percent ethanol in the blend with the remainder being petroleum gasoline. As such, E0 is commonly used to denote ethanol-free gasoline.

${ }^{6}$ Szybist, J. and West, B., "The Impact of Low Octane Hydrocarbon Blending Streams on the Knock Limit of "E85”," SAE Int. J. Fuels Lubr. 6(1):2013, doi:10.4271/2013-01-0888
} 
Octane Number Results

Octane Number test results are shown in Figures 1-3; RON test results are in Figure 1, MON test results are in Figure 2, and the AKI results are shown in Figure 3. The CPS Powershot provides a very modest octane boost at 2 and 4 volume percent blending. Results are also summarized in Table 1. Note that the repeatability of the Octane Number Tests was assessed with a repeat of the 91 RON E0 with 0 and 4\% CPS Powershot additive. These repeat tests were conducted weeks apart and repeatability is excellent with variation of no more than 0.2 Octane Number.

Table 1. Octane Number Results for CPS Powershot Blends

\begin{tabular}{|l|l|l|l|l|l|l|l|l|l|}
\hline \multirow{2}{*}{ Base Fuel } & \multicolumn{3}{|c|}{ Base Fuel, no Additive } & \multicolumn{3}{l|}{$\begin{array}{l}\text { Base Fuel with 2 vol\% } \\
\text { CPS Powershot }\end{array}$} & \multicolumn{3}{c|}{$\begin{array}{l}\text { Base Fuel with 4 vol\% } \\
\text { CPS Powershot }\end{array}$} \\
\cline { 2 - 12 } & RON & MON & AKI & RON & MON & AKI & RON & MON & AKI \\
\hline 72 RON E0 & 72.4 & 70.8 & 71.6 & 72.4 & 71.5 & 72.0 & 73.1 & 72.5 & 72.8 \\
\hline 91 RON E0, Run 1 & 91.0 & 84.8 & 87.9 & 91.4 & 85.1 & 88.3 & 91.8 & 85.4 & 88.6 \\
\hline 91 RON E0, Run 2 & 90.9 & 84.6 & 87.8 & NT $^{a}$ & NT & NT & 92.0 & 85.2 & 88.6 \\
\hline 93 RON E10 & 92.6 & 84.7 & 88.7 & 93 & 84.8 & 88.9 & 93.5 & 85.1 & 89.3 \\
\hline${ }^{a}$ Not Tested & \multicolumn{9}{|c|}{} \\
\hline
\end{tabular}

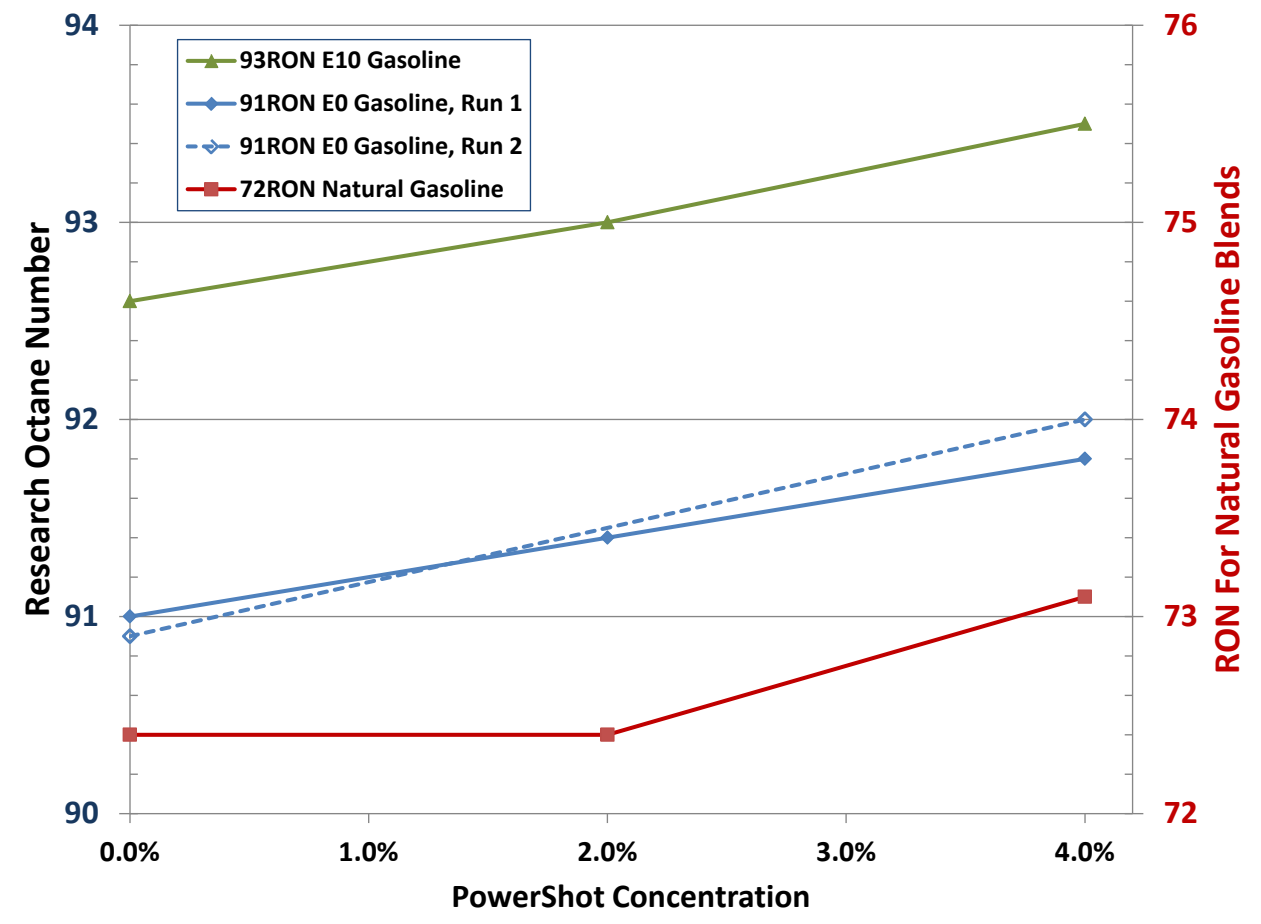

Figure 1. Research Octane Number (RON) for CPS Powershot blends 


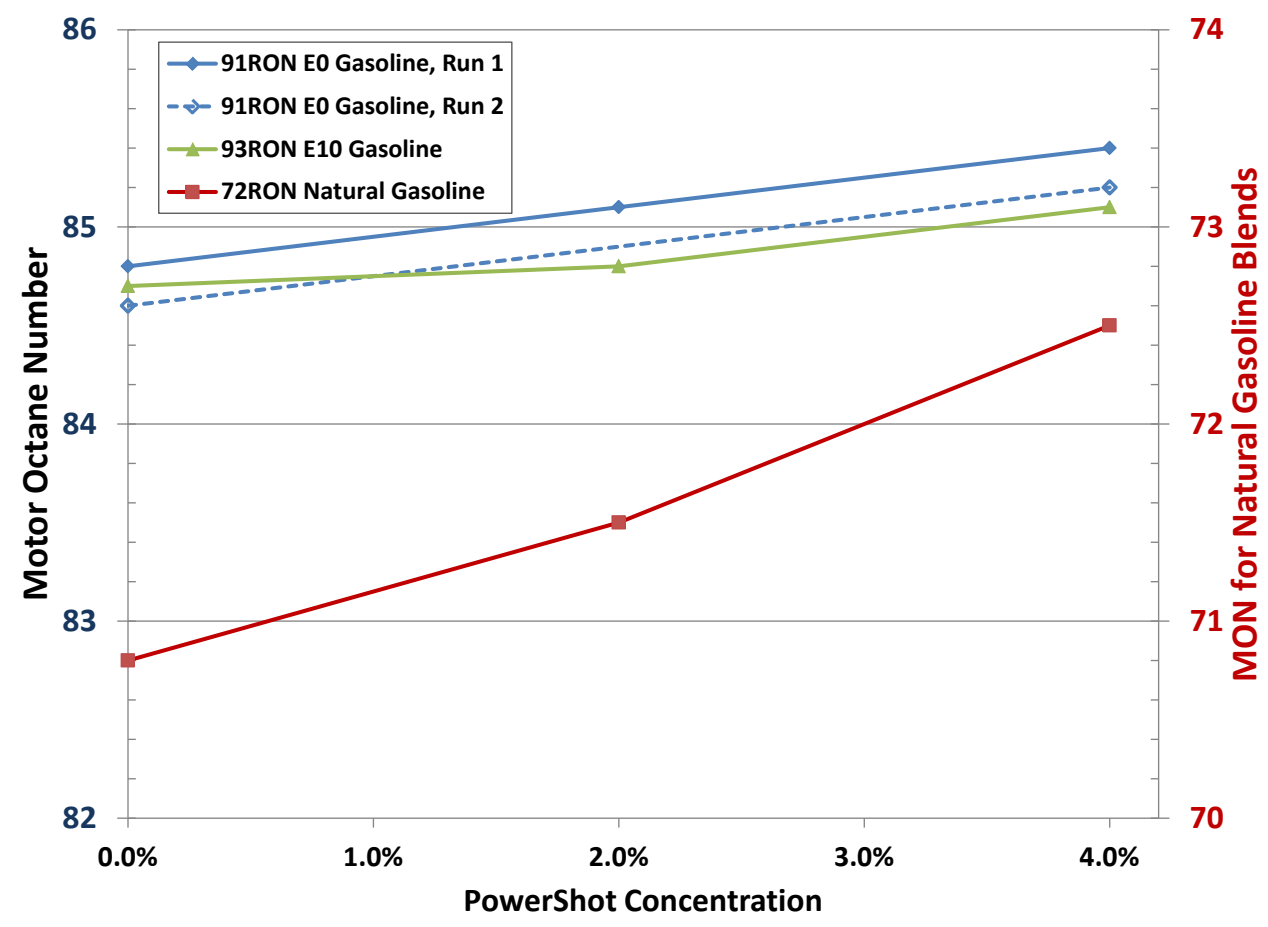

Figure 2. Motor Octane Number (MON) for CPS Powershot blends

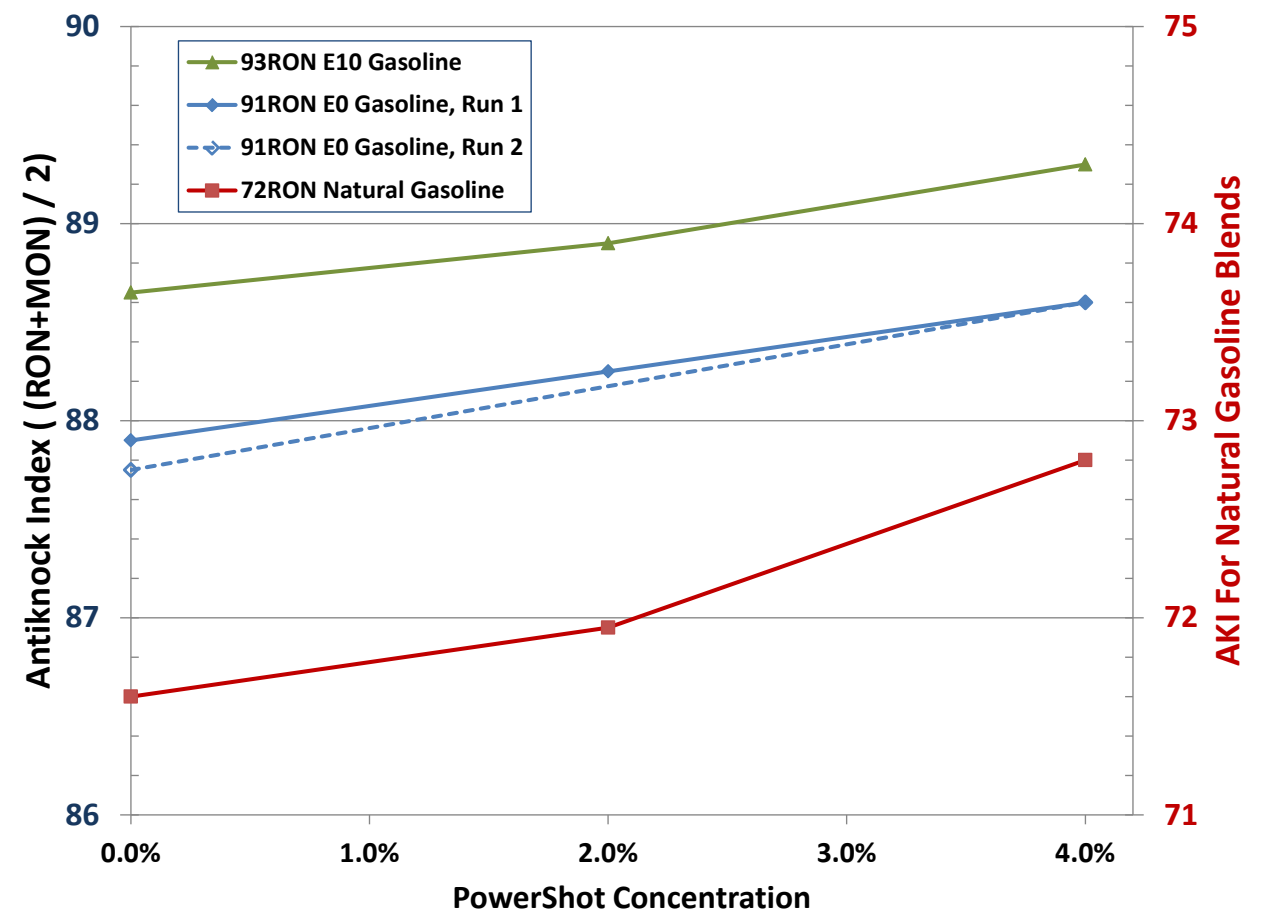

Figure 3. Antiknock Index (AKI) for CPS Powershot blends 


\subsubsection{DISTILLATION AND RVP RESULTS}

The ASTM D4814 specification establishes limits on distillation temperature of spark ignition engine fuels. The temperature at which $50 \%$ of the sample is recovered is denoted T50. Similarly, T90 indicates the temperature at which $90 \%$ has been recovered. Upper limits within D4814 include a maximum $\mathrm{T} 50$ of $250^{\circ} \mathrm{F}$, maximum T90 of $374^{\circ} \mathrm{F}$, and a final boiling point (FBP) of $437^{\circ} \mathrm{F}$. Boiling point information for 2,3-Ditert-butoxypropanol could not be found in the literature, but given its high molecular weight, there was concern about its suitability as a gasoline additive. As such, a neat sample of CPS Powershot was subjected to the ASTM D86 distillation test to determine its boiling range. Additionally, the same fuel blends tested for octane number were analyzed with D86. Results of these distillations are shown in Figure 4.

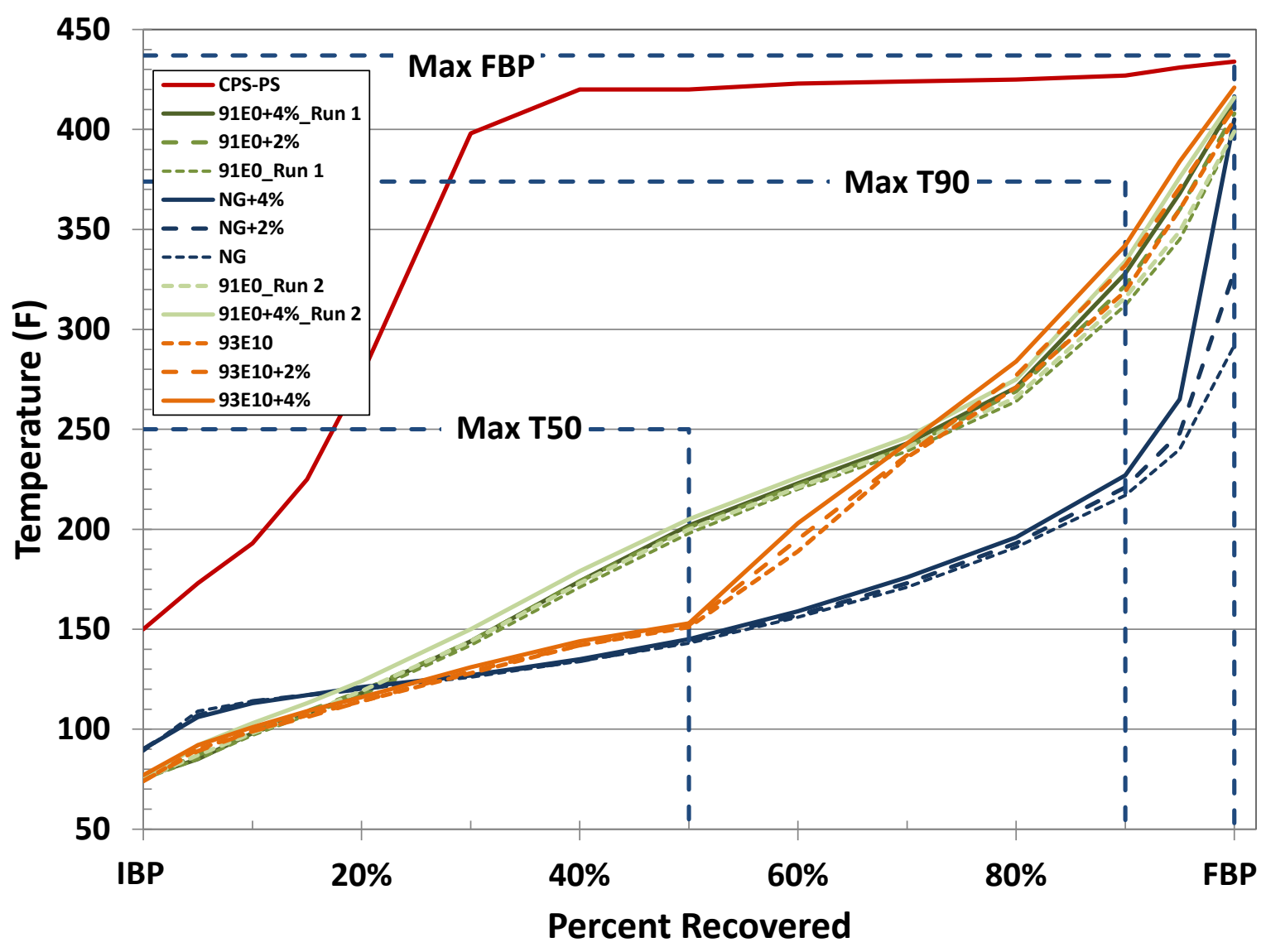

Figure 4. ASTM D86 Distillation for CPS Powershot blends. Max T50, Max T90, and Max FBP denote distillation limits for ASTM D4814.

The CPS Powershot D86 shows an FBP of $434^{\circ} \mathrm{F}$, just below the D4814 maximum for gasoline blends. Note in Figure 4 that the 2 volume \% and 4 volume \% CPS Powershot blends have higher T90 and FBP than the neat blendstocks, as expected. The most dramatic change is in the very light and volatile natural gasoline sample. These results imply that the CPS Powershot components are vaporizing at the end of the distillation near their boiling point. Ethanol is well known for its tendency to increase vapor pressure of E10 gasoline blends, despite its lower vapor pressure in neat 
form. No such behavior is noted in the D86 for the CPS Powershot blends. Similarly, the Reid Vapor Pressure (RVP, ASTM D5191 ${ }^{1}$ ) results show that in all cases, addition of the CPS Powershot lowered the RVP slightly. Table 2 summarizes the results of the RVP tests for all samples.

Table 2. Reid Vapor Pressure Results (psi)

\begin{tabular}{|l|c|c|c|}
\hline \multicolumn{1}{|c|}{ Base Fuel } & $\begin{array}{c}\text { Base Fuel, no } \\
\text { Additive }\end{array}$ & $\begin{array}{c}\text { Base Fuel with 2 } \\
\text { vol\% CPS Powershot }\end{array}$ & $\begin{array}{c}\text { Base Fuel with 4 } \\
\text { vol\% CPS } \\
\text { Powershot }\end{array}$ \\
\hline 72 RON E0 & 10.79 & 10.55 & 10.5 \\
\hline $\begin{array}{l}\text { 11 RON E0, Run } \\
\text { 91 RON E0, Run } \\
\text { 2 }\end{array}$ & 13.75 & 13.65 & 13.63 \\
\hline 93 RON E10 & 13.72 & Not Tested & 13.68 \\
\hline
\end{tabular}

\section{SUMMARY}

The CPS Powershot fuel additive was provided to ORNL for analysis and testing. ORNL GC/MS analysis shows that 3 isomers of the diether form of glyceryl tert-butyl ether make up the majority of the additive. The neat CPS Powershot fuel additive was subjected to a number of standard tests and blended at 2 and 4 volume percent with three relevant gasoline blendstocks; these blends were also subjected to a number of standard fuel tests. Results show that the additive boils at the upper end of the gasoline range, increasing T90 and FBP of the blends tested, and slightly depressing the RVP. ASTM tests for Octane Number show a very modest boost of RON, MON, and AKI at the legal limit of 2 volume percent; Octane Number increase was not significantly dependent on the Octane Number of the blend stock. It is worthy of note that the directions provided on the product packaging indicate that 5 ounces of CPS Powershot can treat up to 25 gallons of fuel; at this treatment rate the additive would be at less than 0.2 volume $\%$ and would not be expected to show any measureable increase in Octane Number.

\footnotetext{
${ }^{1}$ ASTM D5191, “Standard Test Method for Vapor Pressure of Petroleum Products,” available at http://www.astm.org/Standards/D5191.htm
} 


\section{APPENDIX A: CHEMICAL ANALYSIS}

Gas chromatography-mass spectrometry (GC-MS) is widely used for speciation of the volatile and semi-volatile components of biomass-derived liquids. A common method for reporting qualitative GC-MS data of bio-oils is to present the compounds detected based on their percent contribution to the total chromatographic area of all compounds detected in the analysis. A $14 \%$

cyanopropylphenyl/86\% dimethylsiloxane phase (Restek Rtx-1701, dimensions 60 m x $250 \mu \mathrm{m}, 0.25$ $\mu \mathrm{m}$ df) was the column selected for this analysis. Earlier method development showed this system to provide superior resolution of biomass-derived liquids' components compared to other commonly used phases. A sample of CPS Powershot was prepared via a 1000:1 dilution of the additive in trace analytical grade methanol. A methanol blank injection was analyzed to affirm no systemic contamination. The GC-MS instrument parameters were as follows: He carrier gas, $1 \mathrm{~mL} / \mathrm{min}$ constant flow; injection volume, $1 \mu \mathrm{L}$ with port temperature $250^{\circ} \mathrm{C}$ and a split ratio of $30: 1$; initial oven temperature of $45^{\circ} \mathrm{C}, 10$ min hold time with an oven ramp rate at $3{ }^{\circ} \mathrm{C} / \mathrm{min}$ and a final oven temperature $250{ }^{\circ} \mathrm{C}, 5 \mathrm{~min}$ hold time; MSD transfer line, source, and quad set at $280{ }^{\circ} \mathrm{C}, 230^{\circ} \mathrm{C}, 150$ ${ }^{\circ} \mathrm{C}$, respectively, with a solvent delay set to $4.0 \mathrm{~min}$ for methanol; scan range $\mathrm{m} / \mathrm{z} 29-600$.

On a percentage basis estimate, and based on an assumption that the detected compounds have similar instrument response factors (including fully equivalent vaporization in the GC inlet, full passage through the column, and equivalent ionization in the MS), it was found that the CPS Powershot is made up largely of three isomers of the diether form of GTBE (glyceryl tertiary butyl ether, 83\% of total mass detected), with small but significant levels of olefinic impurities, perhaps resulting from auto-condensation from an oxygenate to a vinylic bond (16\% total mass detected), along with nearly negligible content of two monoether isomers, which would be expected as a reaction side product at some level, regardless of the care taken in the preparative synthesis and purification. A summary of the GC/MS results is shown in Table A.1. Although no molecular ion was detected, based on fragments and literature structures, an example representation of one of the possible diether isomers $\left(\mathrm{C}_{11} \mathrm{H}_{24} \mathrm{O}_{3}\right.$, nominal mass $\left.=204 \mathrm{~g} / \mathrm{mol}\right)$, along with its IUPAC name, is shown below (2,3-Ditertbutoxypropanol). Exact structural determination among the three major diether isomers was not undertaken, as they are expected to function similarly in the fuel application.<smiles>CC(C)(C)OCC(CO)OC(C)(C)C</smiles>

\section{2,3-Ditert-butoxypropanol}


Table A.1. GC/MS Results

\begin{tabular}{|c|c|c|c|}
\hline Diether isomers (3) & Abundance & \multicolumn{2}{|c|}{ Percent Composition } \\
\hline 1 & 16500000 & $49.3 \%$ & \\
\hline 2 & 2100000 & $6.3 \%$ & Total \% Diether \\
\hline 3 & 9100000 & $27.2 \%$ & $83 \%$ \\
\hline \multicolumn{4}{|l|}{ Olefinic impurities (2) } \\
\hline 1 & 4200000 & $12.5 \%$ & Total \% Olefinic Impurities \\
\hline 2 & 1200000 & $3.6 \%$ & $16 \%$ \\
\hline \multicolumn{4}{|l|}{ Monoether Isomers (2) } \\
\hline 1 & 190000 & $0.6 \%$ & Total \% Monoether \\
\hline 2 & 190000 & $0.6 \%$ & $1 \%$ \\
\hline Total & 33480000 & $100.0 \%$ & \\
\hline
\end{tabular}




\section{APPENDIX B: SOUTHWEST RESEARCH INSTITUTE TEST REPORTS}

Test reports from Southwest Research Institute are provided. Table B.1 shows the sample name cross reference for the blends submitted.

Table B.1. Sample Names for SwRI Analyses

\begin{tabular}{|l|c|c|c|}
\hline \multicolumn{1}{|c|}{ Base Fuel } & $\begin{array}{c}\text { Base Fuel, no } \\
\text { Additive }\end{array}$ & $\begin{array}{c}\text { Base Fuel with 2 vol\% } \\
\text { CPS Powershot }\end{array}$ & $\begin{array}{c}\text { Base Fuel with 4 vol\% } \\
\text { CPS Powershot }\end{array}$ \\
\hline 91 RON E0, Run 1 & ORNL-GTBE-01 & ORNL-GTBE-02 & ORNL-GTBE-03 \\
\hline 72 RON E0 & ORNL-GTBE-04 & ORNL-GTBE-05 & ORNL-GTBE-06 \\
\hline CPS Powershot (neat) & ORNL-GTBE-07 & NA & NA \\
\hline 91 RON E0, Run 2 & ORNL-GTBE-08 & NA & ORNL-GTBE-09 \\
\hline 93 RON E10 & ORNL-GTBE-10 & ORNL-GTBE-11 & ORNL-GTBE-12 \\
\hline
\end{tabular}




\section{Southwest Research Institute (PPRD) \\ Test Summary Report \\ January 5, 2016 \\ SwRI WO\# 73867}

ASTM D5191 Vapor Pressure of Petroleum Products (Mini Method)

RVP, psi .

DVPE, psi

ASTM D2699 RON.

ASTM D5599 Oxygen and Oxygenates, Weight \%

DIPE.

$<0.1$

ETBE

$<0.1$

EtOH

$<0.1$

iBA

$<0.1$

iPA

$<0.1$

$\mathrm{MeOH}$

$<0.1$

MTBE

$<0.1$

$n B A$

$<0.1$

nPA

sBA.

$<0.1$

TAME

$<0.1$

tBA

$<0.1$

$<0.1$

tPA

$<0.1$

Total Oxygen

$<0.1$

ASTM D86 Distillation, deg. F

IBP

$5 \%$...

$10 \%$

$15 \%$

$20 \%$

$30 \%$

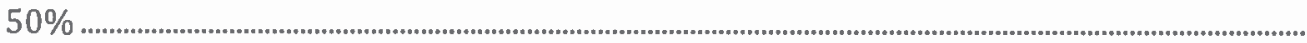

$60 \%$

$70 \%$

220

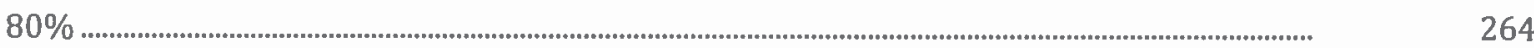

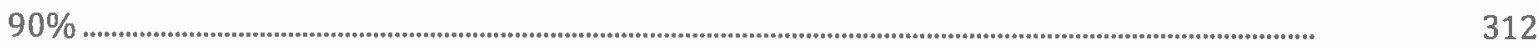

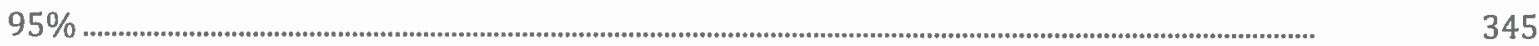

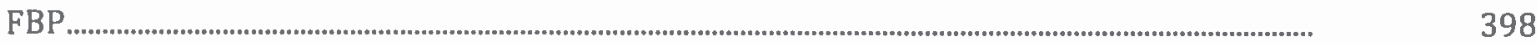

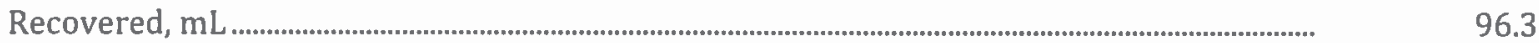

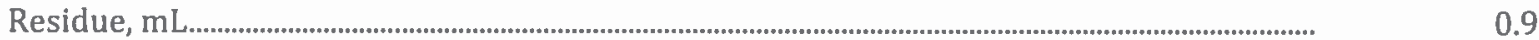

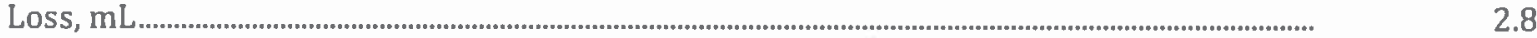




\section{Southwest Research Institute (PPRD) \\ Test Summary Report \\ January 5, 2016 \\ SwRI WO\# 73867}

ASTM D5191 Vapor Pressure of Petroleum Products (Mini Method)

RVP, psi

13.65

DVPE, psi

ASTM D2699 RON

91.4

ASTM D2700 MON.

85.1

ASTM D5599 Oxygen and Oxygenates, Weight \%

DIPE

$<0.1$

ETBE.

$<0.1$

EtOH

$<0.1$

iBA

$<0.1$

iPA

$<0.1$

$\mathrm{MeOH}$

$<0.1$

MTBE

$<0.1$

$n B A$

$<0.1$

$n P A$

$<0.1$

SBA

$<0.1$

TAME

$<0.1$

tBA

$<0.1$

tPA.

$<0.1$

Total Oxygen

ASTM D86 Distillation, deg. $F$

IBP

$5 \%$

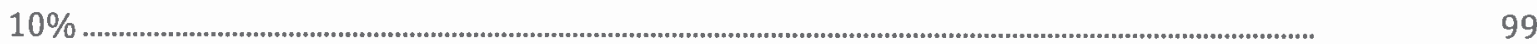

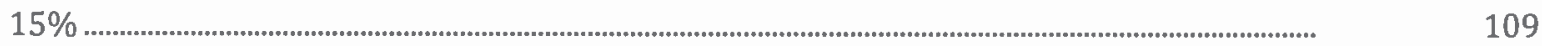

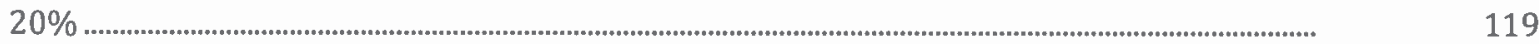

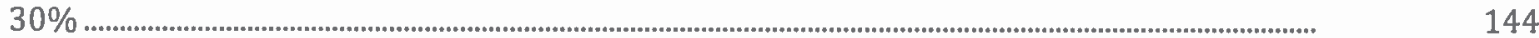

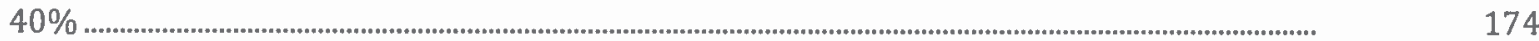

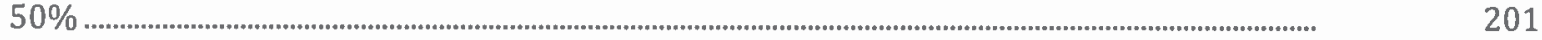

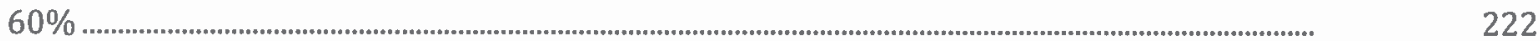

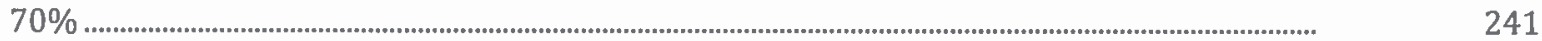

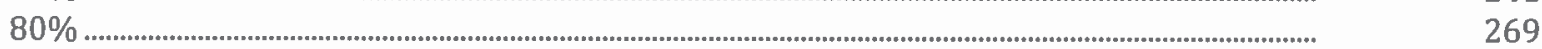

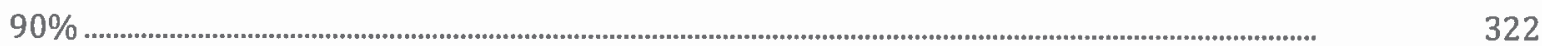

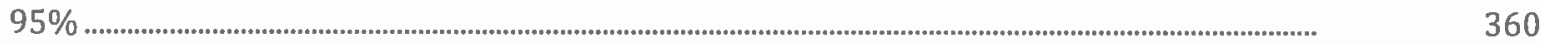

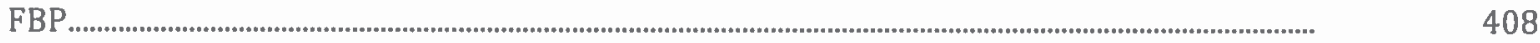

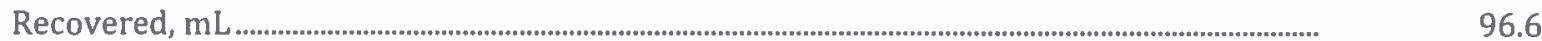

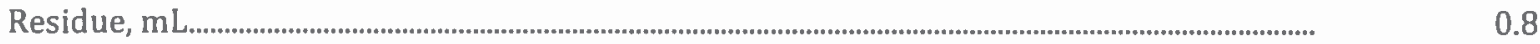

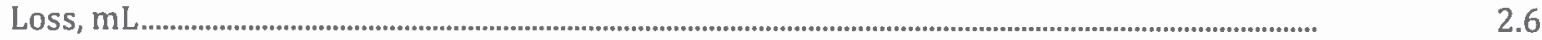




\section{Southwest Research Institute (PPRD) \\ Test Summary Report \\ January 5, 2016 \\ SwRI WO\# 73867}

ASTM D5191 Vapor Pressure of Petroleum Products (Mini Method)

RVP, psi

ASTM D5599 0xygen and Oxygenates, Weight \%

DIPE

ETBE.

$<0.1$

EtOH

$<0.1$

iBA

$<0.1$

iPA

$<0.1$

$\mathrm{MeOH}$

$<0.1$

MTBE

$<0.1$

$n B A$

$<0.1$

nPA

$<0.1$

SBA

$<0.1$

TAME

$<0.1$

tBA

$<0.1$

tPA.

$<0.1$

Total Oxygen

ASTM D86 Distillation, deg. F

IBP

$5 \%$

$10 \%$

$15 \%$

$70 \%$

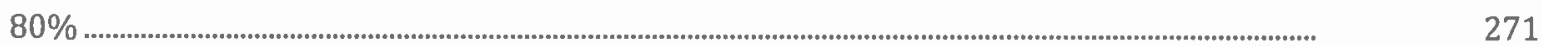

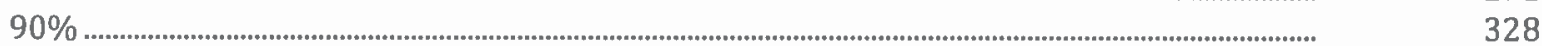

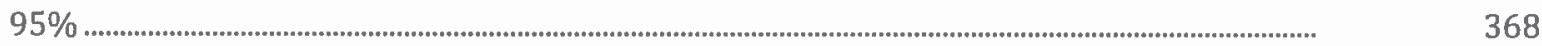

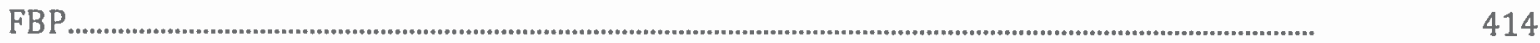

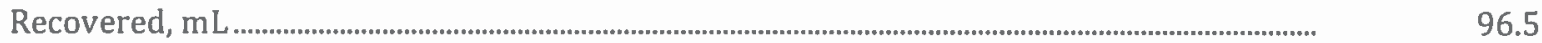

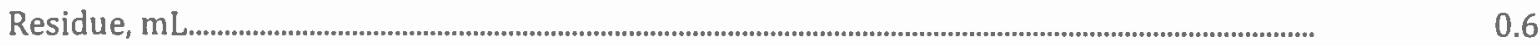

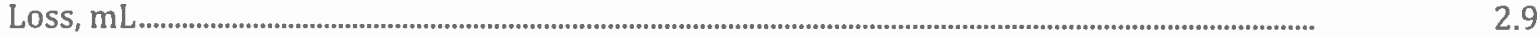




\section{Southwest Research Institute (PPRD) \\ Test Summary Report \\ January 5, 2016 \\ SwRI WO\# 73867}

ASTM D5191 Vapor Pressure of Petroleum Products (Mini Method)

RVP, psi

10.79

DVPE, psi

10.69

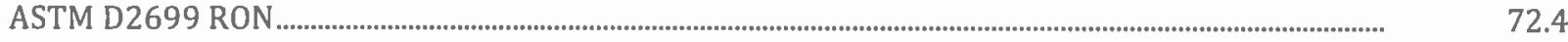

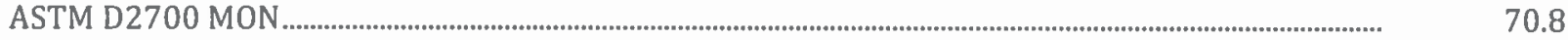

ASTM D5599 Oxygen and Oxygenates, Weight \%

DIPE.

$<0.1$

ETBE

$<0.1$

EtOH

$<0.1$

iBA

$<0.1$

IPA

$<0.1$

$\mathrm{MeOH}$

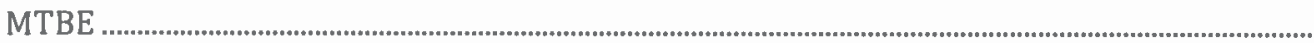

$n B A$

$<0.1$

nPA

$<0.1$

.

sBA.

TAME

tBA

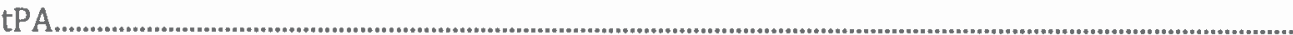

Total Oxygen

$<0.1$

$<0.1$

$<0.1$

$<0.1$

$<0.1$

$<0.1$

$<0.1$

ASTM D86 Distillation, deg. $F$

IBP

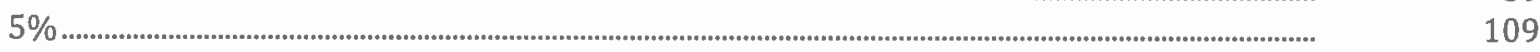

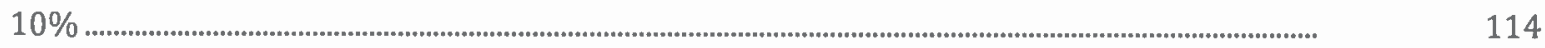

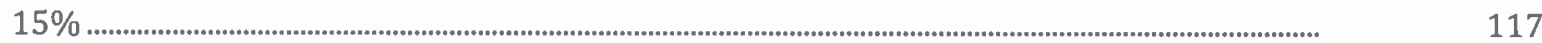

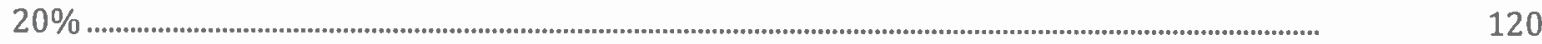

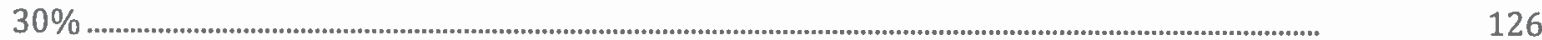

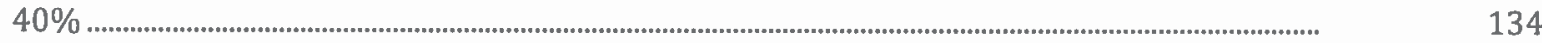

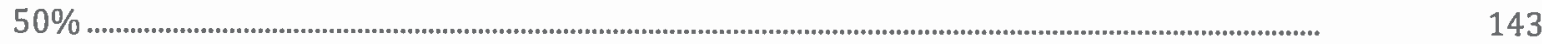

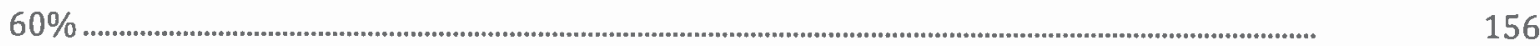

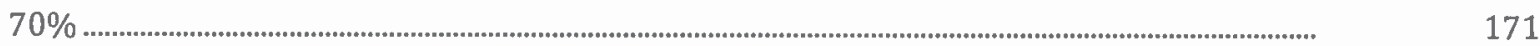

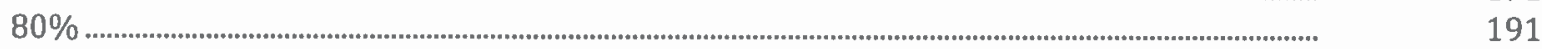

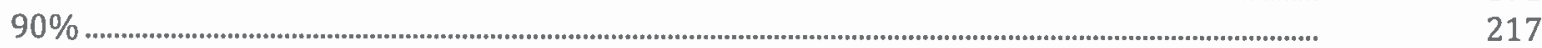

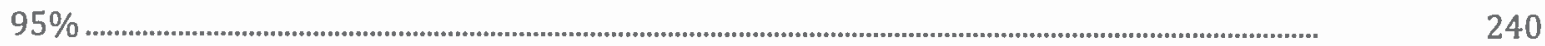

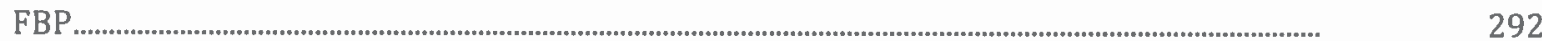

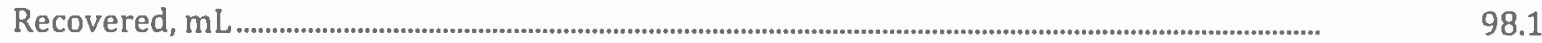

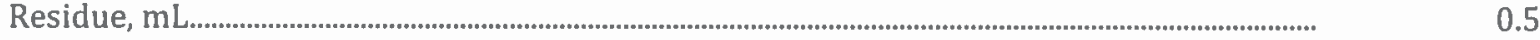

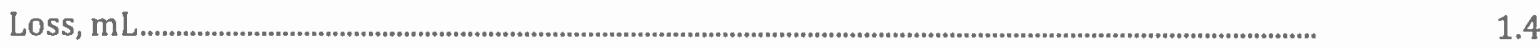




\section{Southwest Research Institute (PPRD) \\ Test Summary Report \\ January 5, 2016 \\ SwRI WO\# 73867}

ASTM D5191 Vapor Pressure of Petroleum Products (Mini Method)

RVP, psi

10.55

DVPE, psi

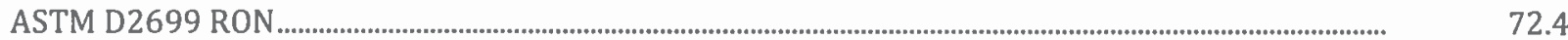

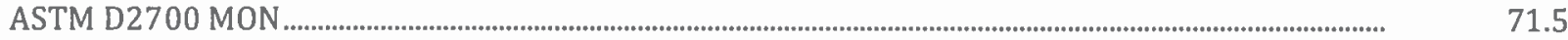

ASTM D5599 Oxygen and Oxygenates, Weight \%

DIPE

$<0.1$

ETBE.

$<0.1$

EtOH

$<0.1$

iBA

$<0.1$

iPA

$<0.1$

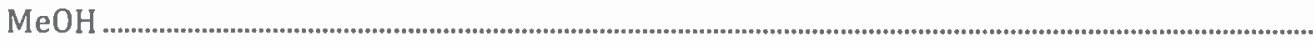

$<0.1$

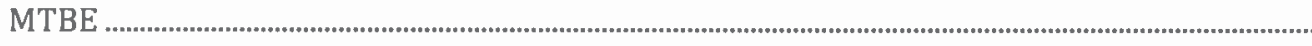

$<0.1$

nBA

$<0.1$

nPA

$<0.1$

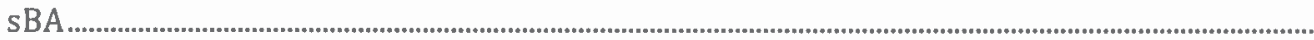

$<0.1$

TAME

$<0.1$

tBA

$<0.1$

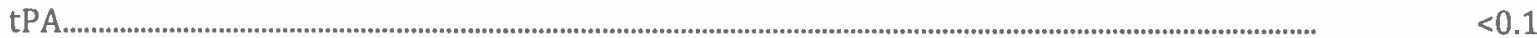

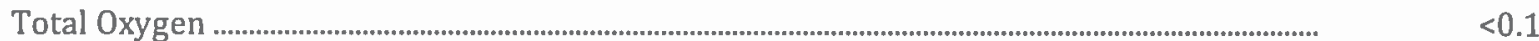

ASTM D86 Distillation, deg. F

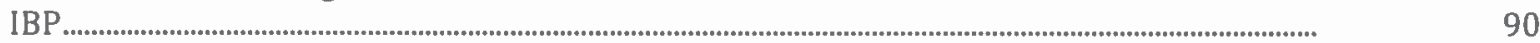

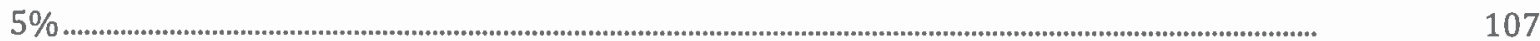

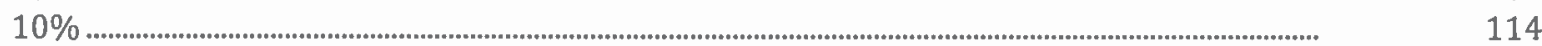

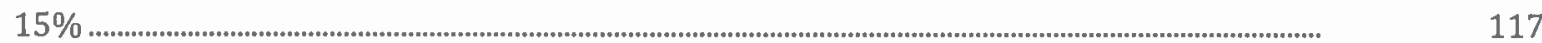

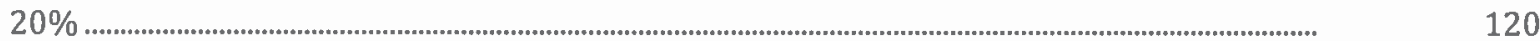

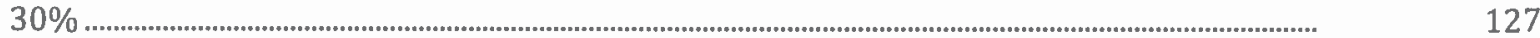

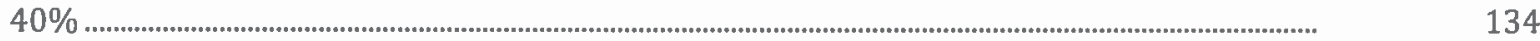

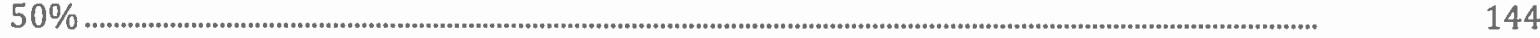

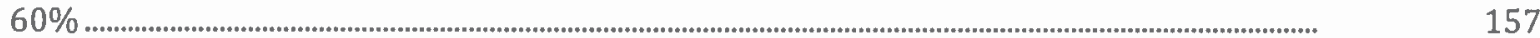

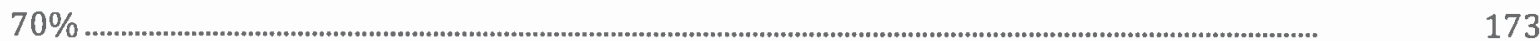

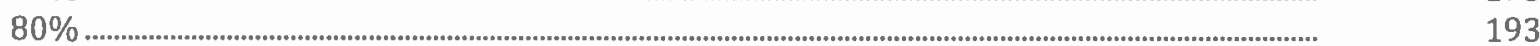

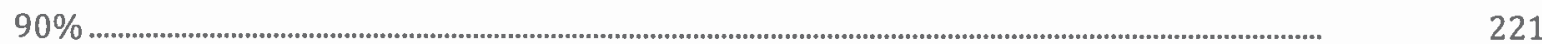

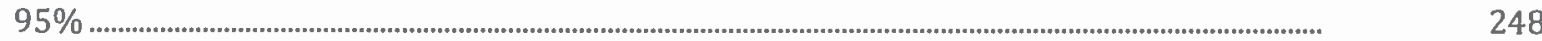

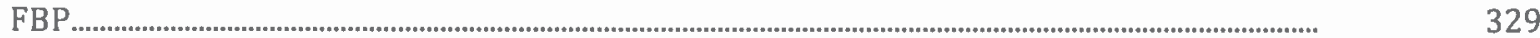

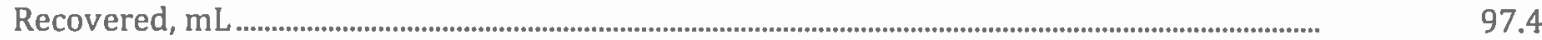

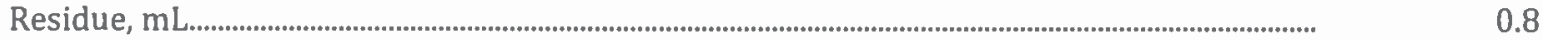

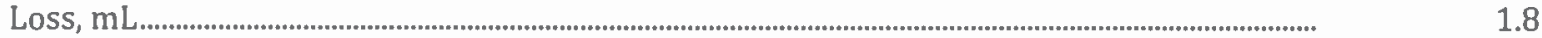




\section{Southwest Research Institute (PPRD) \\ Test Summary Report \\ January 5, 2016 \\ SwRI WO\# 73867}

ASTM D5191 Vapor Pressure of Petroleum Products (Mini Method)

RVP, psi...

10.50

DVPE, psi

10.40

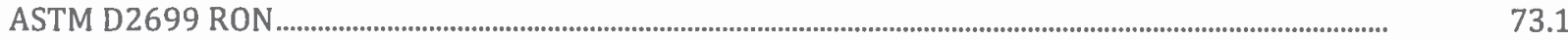

ASTM D2700 MON .

ASTM D5599 Oxygen and Oxygenates, Weight \%

DIPE

$<0.1$

ETBE

$<0.1$

EtOH

$<0.1$

IBA

$<0.1$

IPA

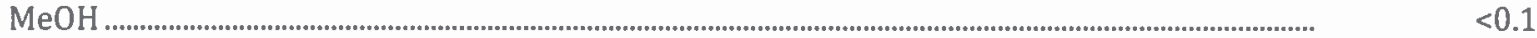

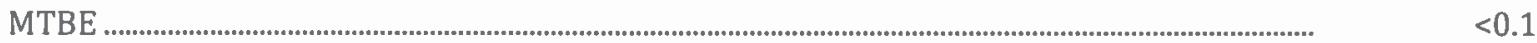

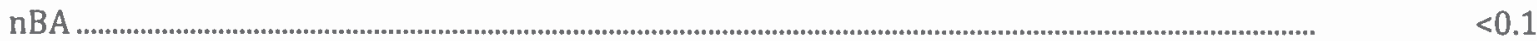

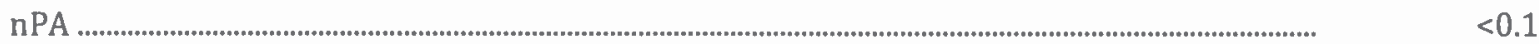

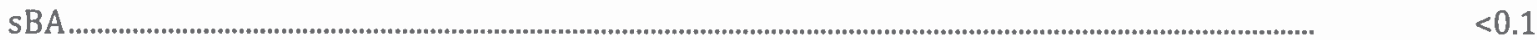

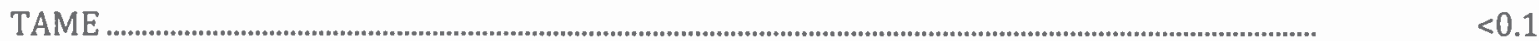

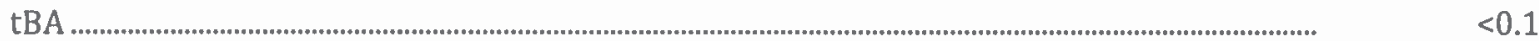

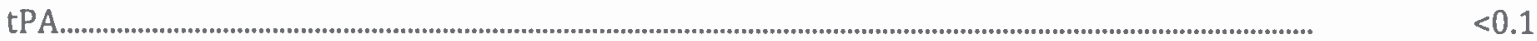

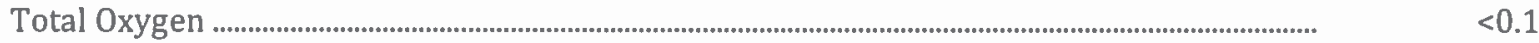

ASTM D86 Distillation, deg. F

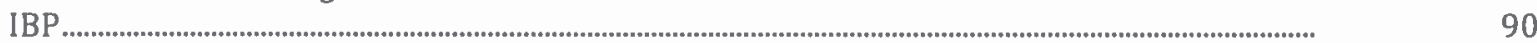

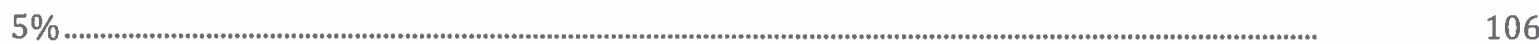

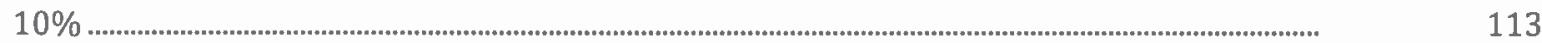

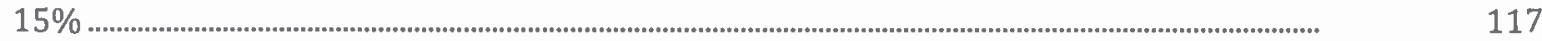

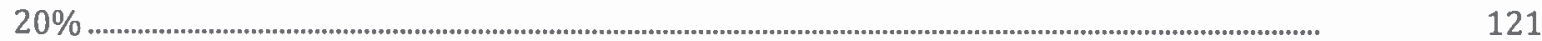

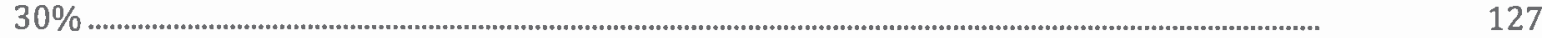

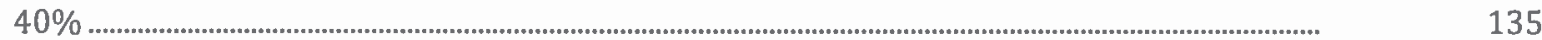

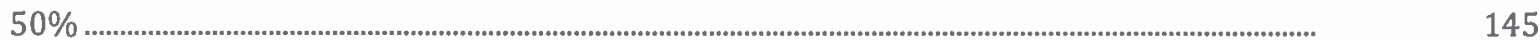

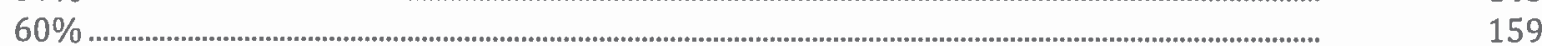

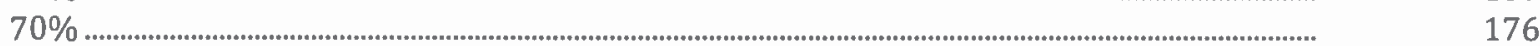

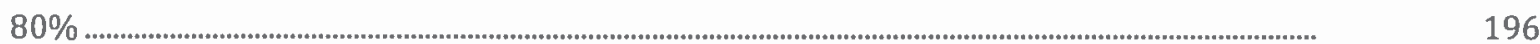

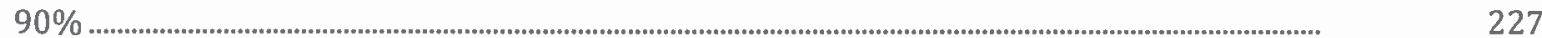

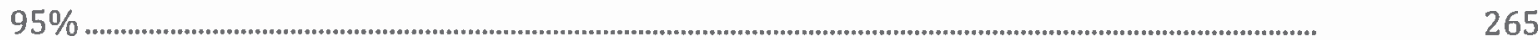

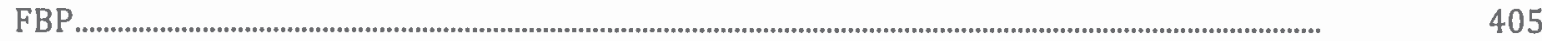

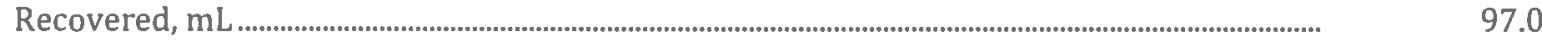

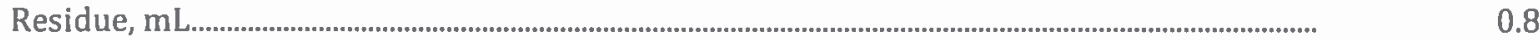

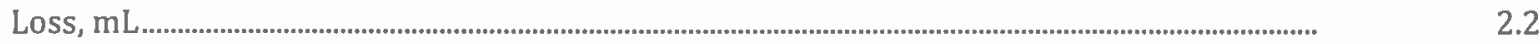




\section{Southwest Research Institute (PPRD) \\ Test Summary Report \\ January 5, 2016 \\ SwRI WO\# 73867}

ASTM D5191 Vapor Pressure of Petroleum Products (Mini Method)

RVP, psi

DVPE, psi

ASTM D4052

API Gravity...

Specific Gravity

Density@15ํ․ $g / m L$

ASTM D5185 Metals by ICP-AES, $p p m^{1}$

Boron

Phosphorus

ASTM D86 Distillation, deg. F

IBP

$5 \%$

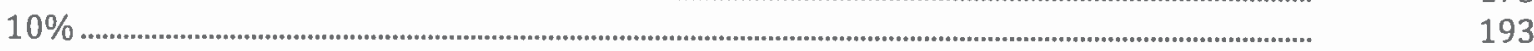

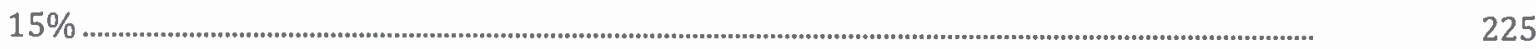

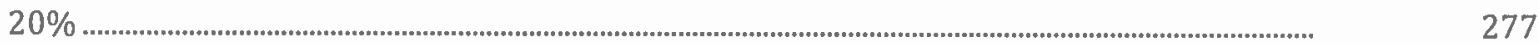

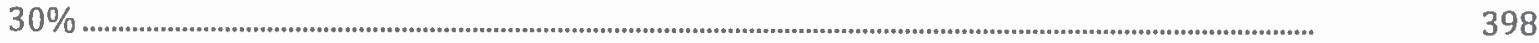

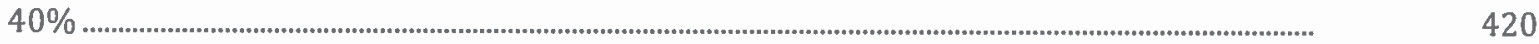

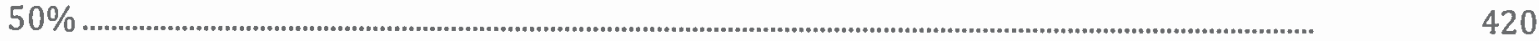

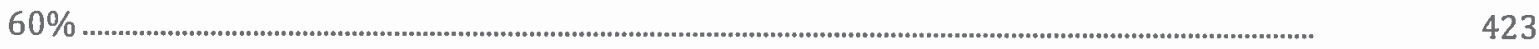

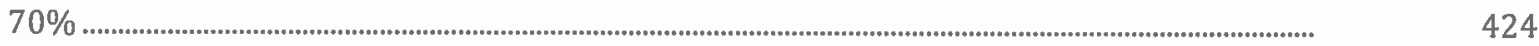

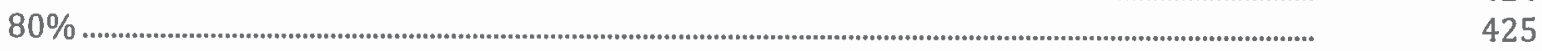

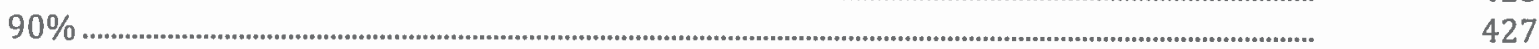

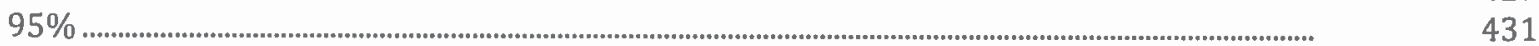

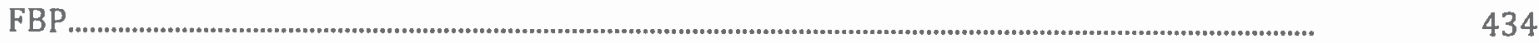

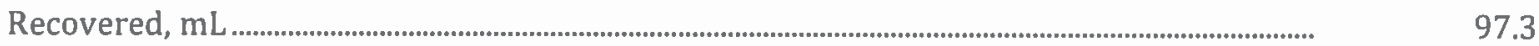

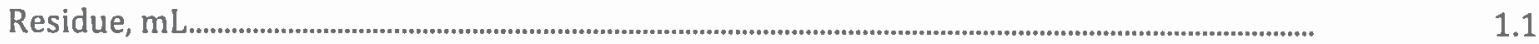

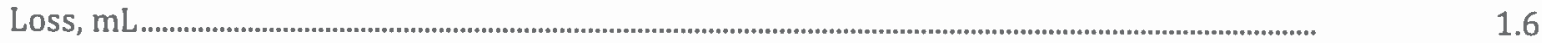

${ }^{1}$ Metals <1: Aluminum, Antimony, Barium, Calcium, Chromium, Copper, Iron, Lead, Magnesium, Manganese, Molybdenum, Nickel, Silicon, Silver, Tin, Zinc, Strontium, Vanadium, Titanium, and Cadmium. Metals <5: Sodium and Potassium. 


\section{Southwest Research Institute (PPRD) \\ Test Summary Report \\ February 19, 2016 \\ SwRI WO\# 74226}

ASTM D5191 Vapor Pressure of Petroleum Products (Mini Method)

RVP, psi.

DVPE, psi.

ASTM D2699 RON.

ASTM D5599 0xygen and Oxygenates, Weight \%

DIPE.

$<0.1$

ETBE.

$<0.1$

EtOH

$<0.1$

iBA

$<0.1$

iPA

$<0.1$

$\mathrm{MeOH}$

$<0.1$

MTBE

$<0.1$

$n B A$

$<0.1$

nPA

$<0.1$

sBA

$<0.1$

TAME

$<0.1$

tBA

$<0.1$

tPA..

$<0.1$

Total Oxygen

$<0.1$

ASTM D86 Distillation, deg. F

IBP

$5 \%$

$10 \%$

98

$15 \%$

108

$20 \%$

119

$30 \%$

$40 \%$

$50 \%$

200

$60 \%$

221

$70 \%$

$80 \%$

$90 \%$

$95 \%$

FBP.

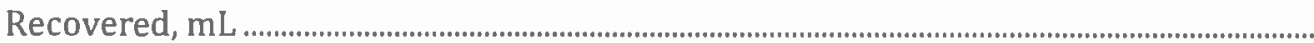

Residue, $\mathrm{mL}$ 


\section{Southwest Research Institute (PPRD) \\ Test Summary Report \\ February 19, 2016 \\ SwRI WO\# 74226}

ASTM D5191 Vapor Pressure of Petroleum Products (Mini Method)

RVP, psi...

DVPE, $p s i$

ASTM D5599 Oxygen and Oxygenates, Weight \%

DIPE.

ETBE.

$<0.1$

EtOH

$<0.1$

iBA

$<0.1$

iPA

$<0.1$

$\mathrm{MeOH}$

$<0.1$

MTBE

$<0.1$

$n B A$

$<0.1$

nPA

$<0.1$

sBA

$<0.1$

TAME

$<0.1$

tBA

$<0.1$

tPA

$<0.1$

Total Oxygen

$<0.1$

ASTM D86 Distillation, deg. F

IBP

74

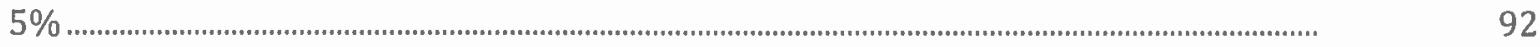

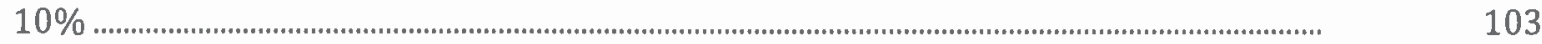

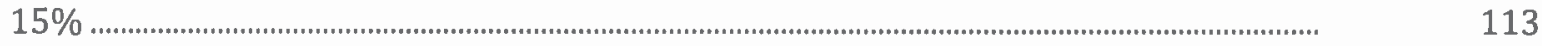

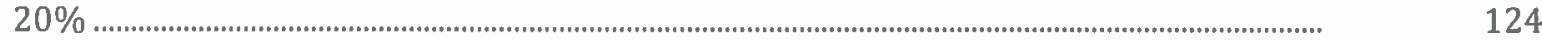

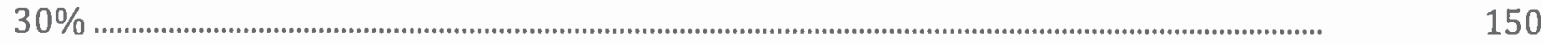

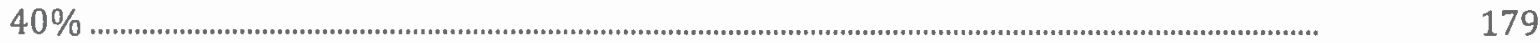

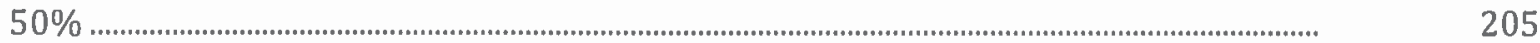

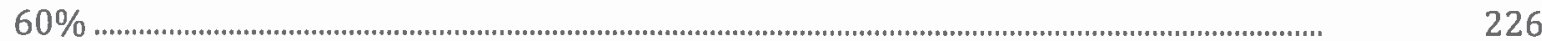

$70 \%$

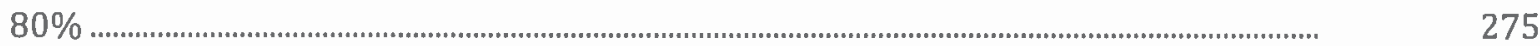

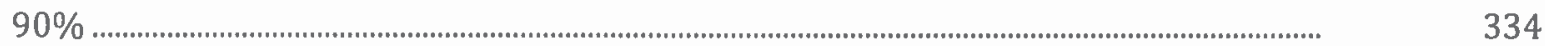

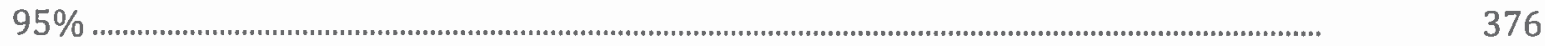

FBP

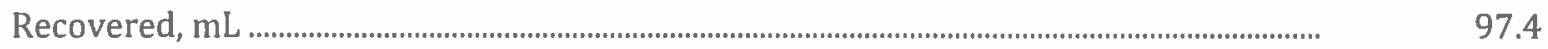

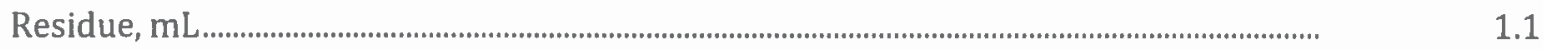

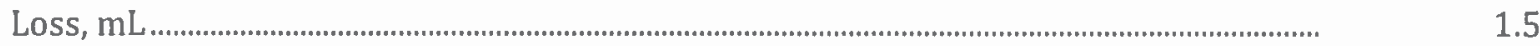




\section{Southwest Research Institute (PPRD) \\ Test Summary Report \\ February 19, 2016 \\ SwRI WO\# 74226}

ASTM D5191 Vapor Pressure of Petroleum Products (Mini Method)

RVP, psi...

DVPE, psi

ASTM D2699 RON

ASTM D5599 0xygen and 0xygenates, Weight \%

DIPE.

ETBE.

EtOH.

iBA

$<0.1$

IPA

$<0.1$

$\mathrm{MeOH}$

$<0.1$

MTBE.

$<0.1$

$n B A$

$<0.1$

$n P A$

$<0.1$

sBA

$<0.1$

TAME.

$<0.1$

tBA

$<0.1$

tPA.

$<0.1$

Total Oxygen.

ASTM D86 Distillation, deg. F

IBP

$5 \%$

$10 \%$

$15 \%$

$20 \%$

114

$30 \%$

128

$40 \%$

142

$50 \%$

151

$60 \%$

189

$70 \%$

236

$80 \%$

271

$90 \%$

$95 \%$

FBP

Recovered, $\mathrm{mL}$....... 97.0

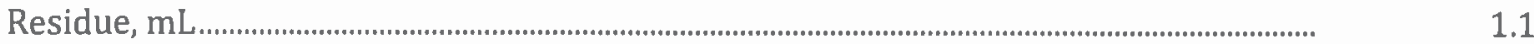

Loss, $\mathrm{mL}$ 


\section{Southwest Research Institute (PPRD) \\ Test Summary Report \\ February 19, 2016 \\ SwRI WO\# 74226}

ASTM D5191 Vapor Pressure of Petroleum Products (Mini Method)

RVP, psi...

DVPE, psi...

ASTM D2699 RON.

ASTM D5599 0xygen and 0xygenates, Weight \%

DIPE.

ETBE.

EtOH.

iBA

$<0.1$

iPA

$<0.1$

$\mathrm{MeOH}$.

$<0.1$

MTBE

$<0.1$

$n B A$

$<0.1$

nPA

$<0.1$

sBA

$<0.1$

TAME

$<0.1$

tBA

$<0.1$

tPA.

$<0.1$

Total Oxygen

3.49

ASTM D86 Distillation, deg. $F$

IBP

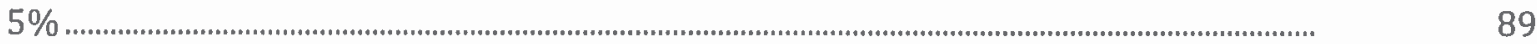

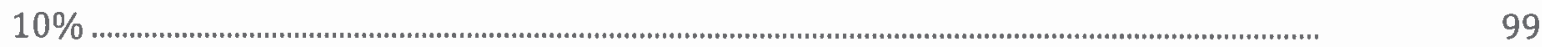

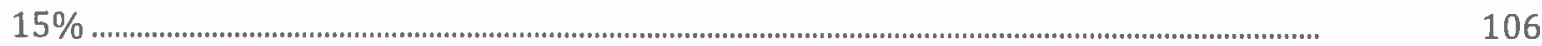

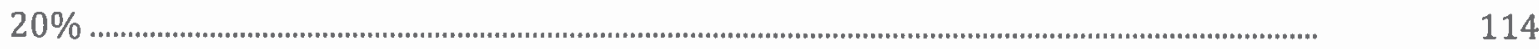

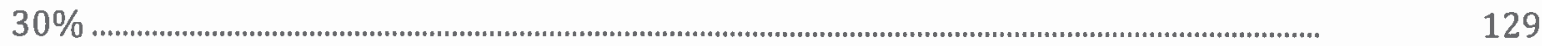

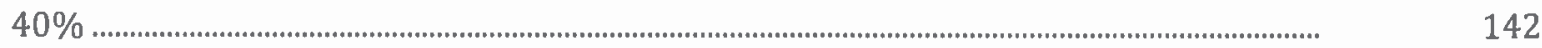

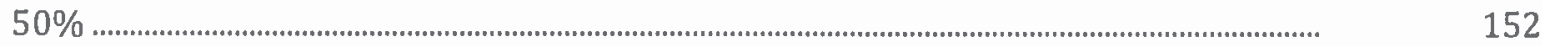

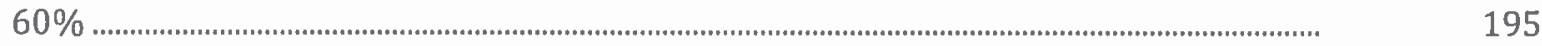

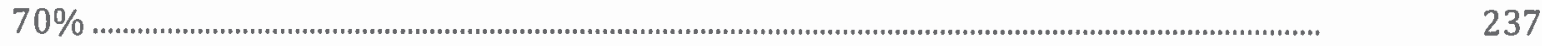

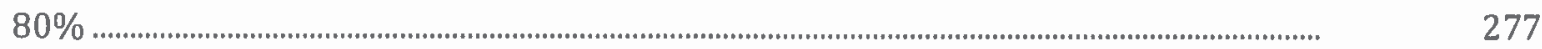

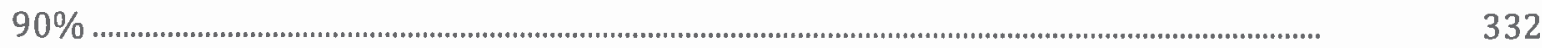

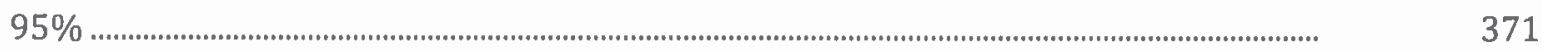

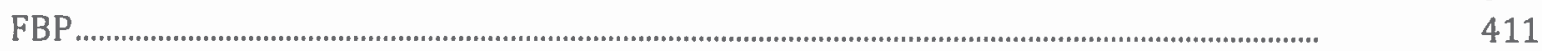

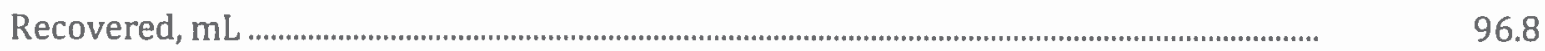

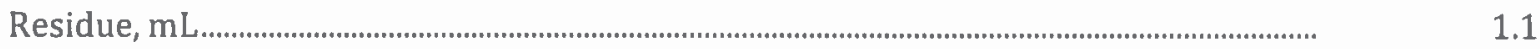

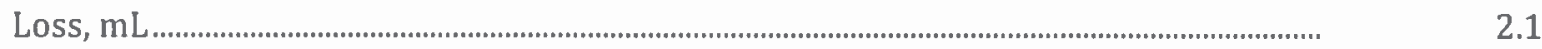




\section{Southwest Research Institute (PPRD) \\ Test Summary Report \\ February 19, 2016 \\ SwRI WO\# 74226}

ASTM D5191 Vapor Pressure of Petroleum Products (Mini Method)

RVP, psi.....

DVPE, $p s i$.

ASTM D2699 RON

ASTM D5599 0xygen and Oxygenates, Weight \%

DIPE

ETBE.

EtOH

9.76

iBA

$<0.1$

iPA

$<0.1$

$\mathrm{MeOH}$

$<0.1$

MTBE

$<0.1$

nBA

$<0.1$

nPA

$<0.1$

SBA

$<0.1$

TAME

$<0.1$

tBA

$<0.1$

tPA...

$<0.1$

Total Oxygen

ASTM D86 Distillation, deg. $F$

IBP

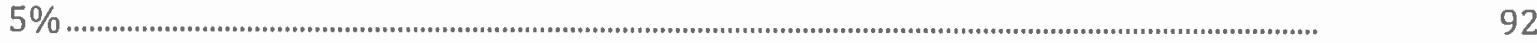

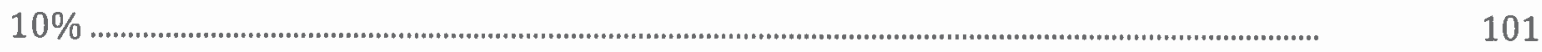

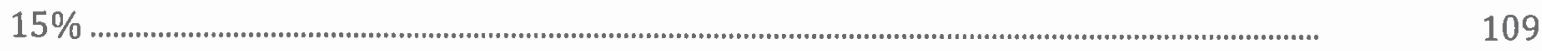

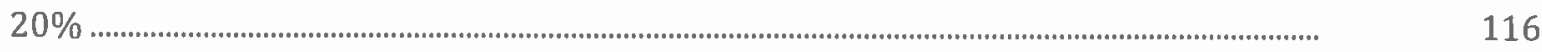

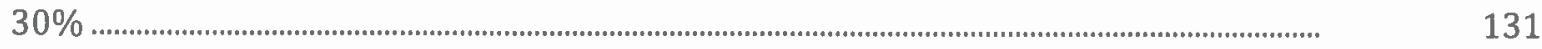

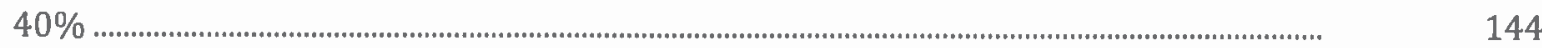

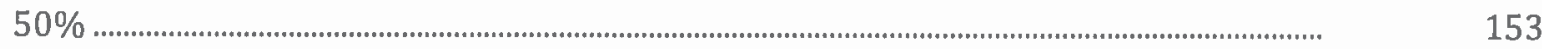

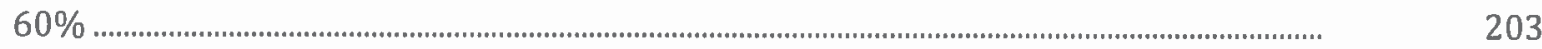

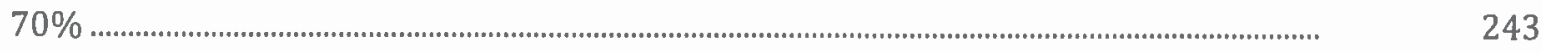

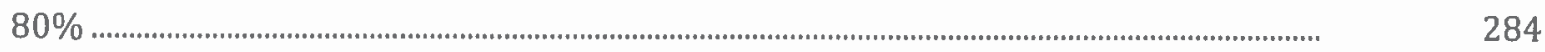

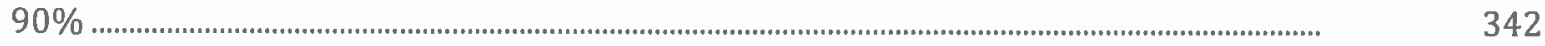

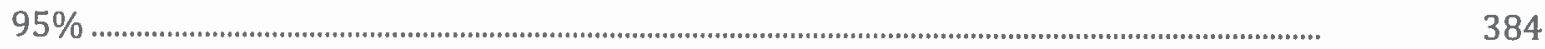

FBP

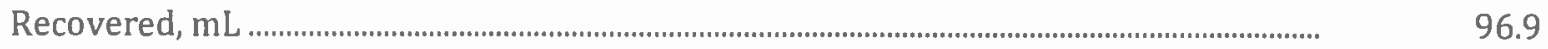

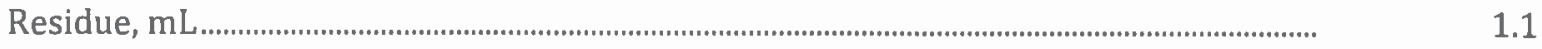

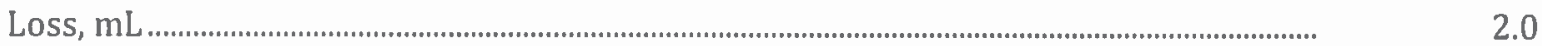

